\title{
Geologic and economic potentials of minerals and industrial rocks in Jordan
}

\author{
Hani Alnawafleh, Khalid Tarawneh, Rami Alrawashdeh*
}

Department of Mining Engineering, Faculty of Engineering, Al-Hussein Bin Talal University, Ma’an, Jordan;

*Corresponding Author: r_rawash@yahoo.com.au, hanialnawafleh@ahu.edu.jo, khtarawneh62@yahoo.com

Received 2 April 2013; revised 4 May 2013; accepted 12 May 2013

Copyright (C) 2013 Hani Alnawafleh et al. This is an open access article distributed under the Creative Commons Attribution License, which permits unrestricted use, distribution, and reproduction in any medium, provided the original work is properly cited.

\section{ABSTRACT}

This work discusses status of the geologic and economic potentials of minerals and industrial rocks in Jordan. The major mineral resources are presented in details and the paper is designed to cover the lack of published data in this field. Geologically, the structural framework of Jordan is controlled largely by Arabian Nubian Shield in the south, block-faulted areas in the east, upwarping in north and east, and Wadi Araba-Dead Sea Transform Fault in the western part. The geologic environments include Precambrian crystalline basement (Late Proterozoic) of Arabian Nubian Shield (ANS) that is composed of igneous and metamorphic rocks at southwestern part. Paleozoic rocks at southern and southeastern part consist of clastic minerals which are dominated by sandstone, whereas Mesozoic sedimentary rocks are widespread throughout southwestern, northern to southeastern parts of the country. They mainly consist of major industrial rocks and minerals such as phosphate, oil shale, limestone, dolomite, chalk, marble, gypsum, diatomite and tripoli. Cenozoic Era is composed of sedimentary and volcanic rocks in different parts of Jordan. There are more than twenty nonmetallic minerals and four main metallic deposits within the various geologic environments. This paper summarizes their distribution, chemical and mineralogical characteristics, in addition to their production statistics.

Keywords: Jordan; Geology; Industrial Minerals; Metallic Minerals; Mining

\section{INTRODUCTION}

Jordan occupies an area of $89,556 \mathrm{~km}^{2}$, between la- titudes $29^{\circ}$ and $33^{\circ}$ north and longitudes $34^{\circ}$ and $39^{\circ}$ east. The average temperature in Amman is $8^{\circ} \mathrm{C}$ in January, $18^{\circ} \mathrm{C}$ in April and $28^{\circ} \mathrm{C}$ in July. There are many cases where summer temperatures can go up to $40^{\circ} \mathrm{C}$ and winter temperatures can go down below freezing point. Aqaba and the Dead Sea areas are warm winter resorts. Annual rainfall reaches $200-600 \mathrm{~mm}$ in northwestern part of the country and declines progressively towards eastern and southern deserts. As shown in Figure 1, Jordan has been divided into seven geomorphological provinces [1].

Since the Bronze Age, ca. 3500 - 1500 BC; Jordan has witnessed an ancient iron and copper mining activities. At one time, mining of industrial minerals and rocks was an important part of the economy. In Jordan, there are

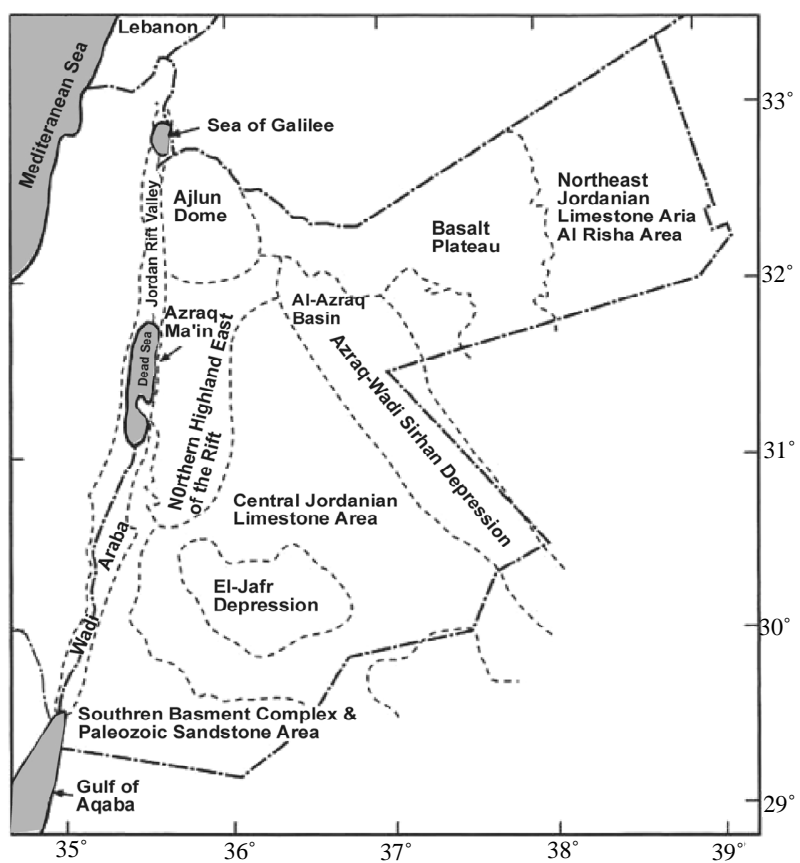

Figure 1. Jordan's major morphological units [1]. 
more than 56 mining facilities which employ more than 9500 people at several mining industries.

The mining sector contribution to Gross National Product (GNP) in the period 2004 to 2008 ranges from $10.5 \%$ to $12 \%$ [2]. This comprises one-third of total revenues from foreign trade of the country, which is equivalent according to official statistics of \$US 2.1 billion out of \$US 5.6 billion of total exports revenues in 2008 [3].

Potash industry led the contribution among all mining products; where its share was 3.9\% to the estimated GNP, followed by phosphate, fertilizers, cement, acids, quarries, bromine with a share of $2.9 \%, 2.8 \%, 2.2 \%, 1.6 \%$, $0.8 \%, 0.7 \%$ respectively. In the last decade, Jordan was among the ten largest phosphate countries in the world. It is estimated that more than $60 \%$ of the area of Jordan has phosphate-bearing deposits at varying depths.

Comprehensive geological studies were carried for a long period. One of the first missions was the American mission to discover the Dead Sea, followed by studies of Lartet [4] and Blanckenhorn [5,6] who published the geological map of Jordan. The activities of geological mapping increased significantly after that in the work of Cox [7,8], Blake [9,10], Ionides and Blake [11], they published the first report on water resources, geology, soil, mineral and hydrogeological correlations of Transjordan. Geology and the evolution of Jordan and Palestine have been studied by Picard [12] and Shaw [13].

Geological map of Jordan at scale of 1:250,000 was published by Quennell [14,15], whereas Wetzel and Morton [16] published detailed study of the geology of Jordan. Cooperative geologic research and assistance was provided by the German Geological Survey for the period 1961-1968 under supervision of Prof. Bender, who published new version of geological map of Jordan at scale 1:250,000. Since 1965, mineral exploration was carried out and completed in the latest years by governmental sector. The accumulation of geologic information from government surveys began in 1965-1968 when the Natural Resources Authority was established. In cooperation with British Geological Survey since 1980-1989, many geological maps have been published at scale of 1:50,000. Most recent phase of accelerated mineral exploration has occurred since 1990, following the privatization of the mining industry and revision of mining regulations.

The discussion presented here focuses on the geology and mining industry of Jordan that drawn largely from the work authors and various other efforts, in particular, those of Burdon [17], Masri [18], MacDonald and Partner [19], Bender [1,20-22], Parker [23], Phoenix [24], Hagen [25], Abed [26,27], Abu Ajamieh, et al. [28], Powell [29-31], Abed and Omari [32], Khoury and Ibra- him [33], Ibrahim, et al. [34], Khoury [35] and Khoury, et al. [36] and that work of the Natural Resources Authority of Jordan (NRA). This article addresses the status of mineral industry in Jordan by giving a thorough description of its major mineral resources.

\section{Geology, Structural Setting and Sedimnetation}

Jordan lies along the northern edge of the Arabian Plate, whereas the southern part is exposed by Arabian Nubian Shield (ANS) which occupies $10 \%$ of the area of Jordan (Figure 2). The distribution of rocks since Precambrian in Jordan is shown in Figure 3.

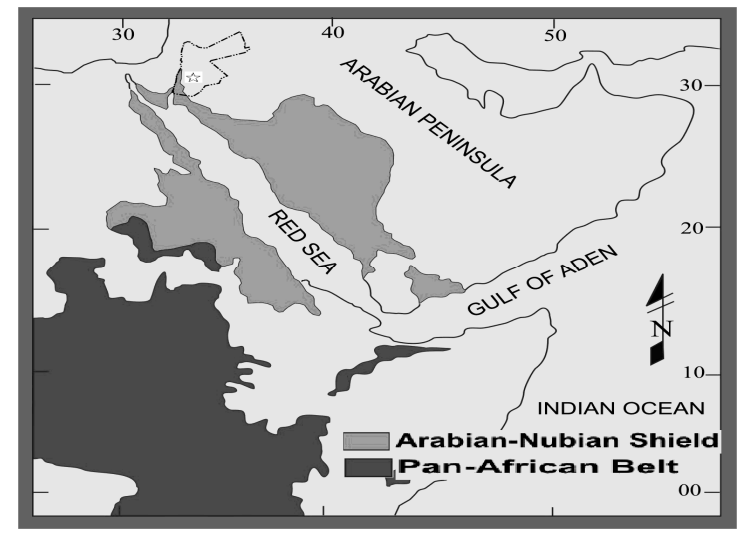

Figure 2. Location of Jordan (with star in the figure) within Arabian Nubian Shield at Arabian Peninsula [27].

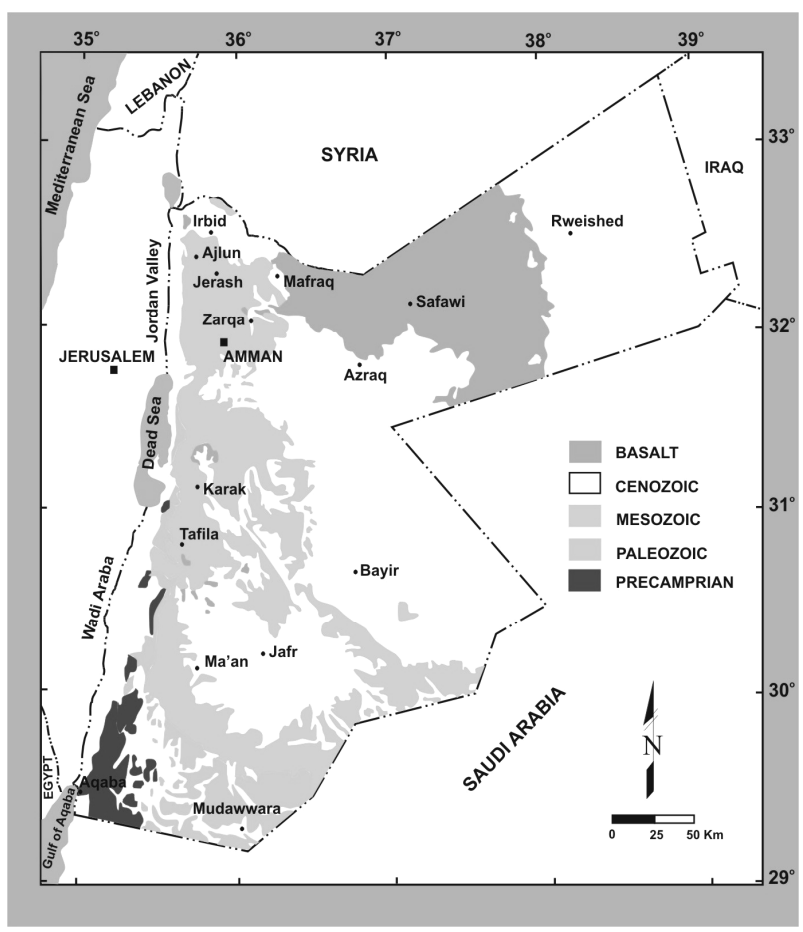

Figure 3. General geological map of Jordan, showing the distribution of the main rocks [27]. 
Precambrian basement rocks of this shield belong to Araba and Aqaba complexes (Late Proterozoic) [37] and comprise metavolcanic, metasedimentary, gneiss and migmatite belts produced in arc environments intruded by post tectonic granites and granodiorites [1].

Uplift and erosion preceded the deposition of Sarmuj Conglomerates (Late Proterozoic) and the Slate Graywacke Series, which are separated by a profound unconformity from the older Proterozoic rocks [22]. The end of the Precambrian is marked by uplifting, regional erosion and peneplanation (Figure 4) in the south of Jordan [27]. After the beginning of the Cambrian, the paleogeographic evolution was controlled by the following factors: 1) Transgression and regression of the Tethys Ocean several times which occupied the region of west and northwest of Jordan; 2) Wadi Araba-Dead Sea-Jordan Valley geosuture, between Palestine Tectonic Block in the west and Jordan Block in the east; 3) The Nubian-Arabian Shield in southeast and south, followed by mechanical and chemical weathering products which transported into the shelf of the Tethys Ocean, or continental clastic sediments were deposited during the regression of the Tethys $[1,27]$.

Paleozoic rocks lie unconformably on Precambrian rocks in south and southeastern part of Jordan (Figure 5). Devonian and Carboniferous rocks have not been defined in Jordan. Major transgression of the Tethys reached the east side of the Wadi Araba and covered central and northern Jordan [27].

Shallow marine limestone, dolomite, and fine grained sandstone were deposited, while in south and southeast Jordan, the continental deposition of sandstone continued. During Ordovician and Silurian continental deposition of clastic sediments was resumed for period of time, as indicated by red-brown coarse sandstone and red sand shale intercalated in some parts with marine sequence.

Paleozoic rocks are the main target for sandstones and water reservoirs in Jordan, while in North Africa are target for petroleum and gas [27,30]. Paleozoic rocks are the main target for sandstones and water reservoirs in

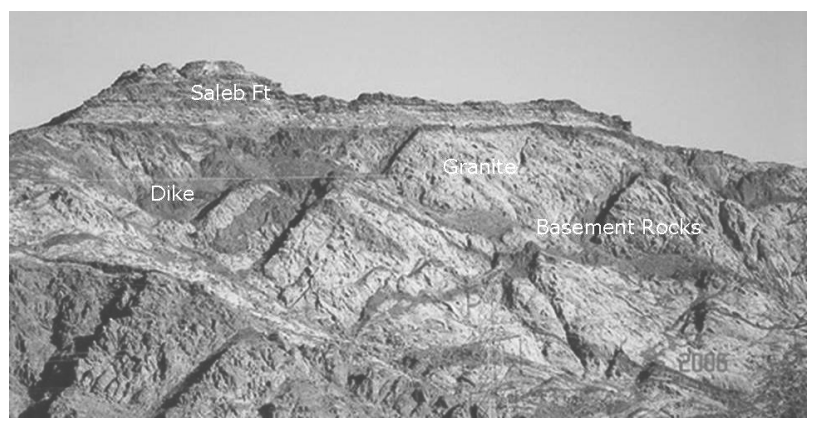

Figure 4. The peniplanation surface between Precambrian rocks and the Cambrian arkosic sandstone North of Quierah, South Jordan.

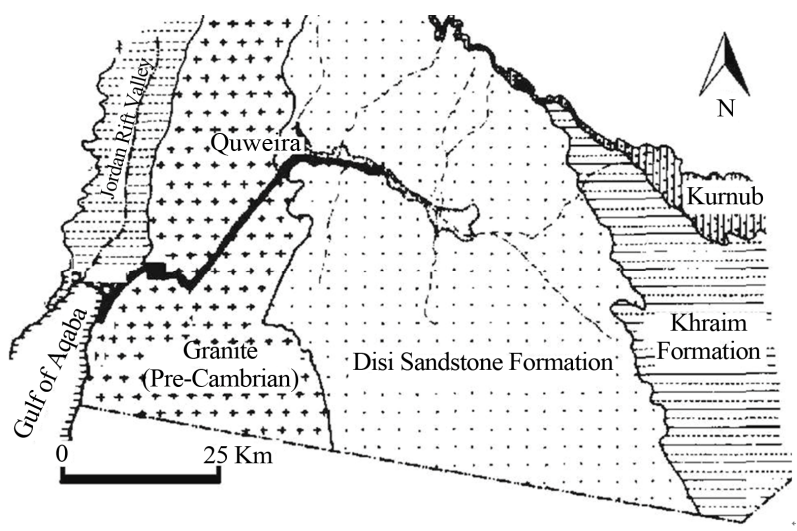

Figure 5. Precambrian and Palaeozoic in Southern Jordan [26].

Jordan, while in North Africa are target for petroleum and gas $[27,30]$.

Mesozoic rocks cover large areas in Jordan, particularly in eastern part of the rift, southeastern, central and northern parts of the country. Most of these rocks were deposited in marine environment. Meanwhile, the lower Cretaceous is a source of sandstone and deposited in continental environment, while the upper Cretaceous rocks have the dominant distribution and cover around $60 \%$ of the country. It is a source of oil shale, phosphate, gypsum, limestone, dolomite, marble, diatomite, porcellanite, and tripoli. The main phosphate mines in Jordan belong to upper Cretaceous age (Campanian-Maastrichtian) [27].

Cenozoic rocks (Tertiary and Quaternary) cover many parts of country and were deposited in shallow marine and estuarine environment [26], mainly composed of chert, limestone, chalk, marl, conglomerate and evaporates. Basalt of Neogene-Quaternary age covered mainly the northeast Jordan, and isolated areas in central, southern part and along the Jordan rift. Sedimentary rocks of young ages are present in some areas including lake deposits, alluvial sands, conglomerates, gypsum, bentonite, basalt and gravels are scattered throughout Jordan [28].

Structurally, Bender [1] subdivided the structural framework of Jordan into the following structural elements: 1) Arabian Nubian Shield (ANS) in the south; 2) Block-Faulted areas in the east; 3) Upwarping in north and east; 4) Wadi Araba-Dead Sea Transform Fault in the western part (Figure 6). The origin of the ANS was subjected to geosynclines and plate tectonic activities, accompanied with island arc accretion and sometimes associated with subduction zones which are indicated by the presences of ophiolites in the Arabian Peninsula [27]. Groups of faults cut Jordan as normal faults or horst and grabens with northeast direction; faults with directions N-S, N-NE, E-W, NE-SW. Upwarping in north and east are represented by folding as Ajlun dome, synclines as 


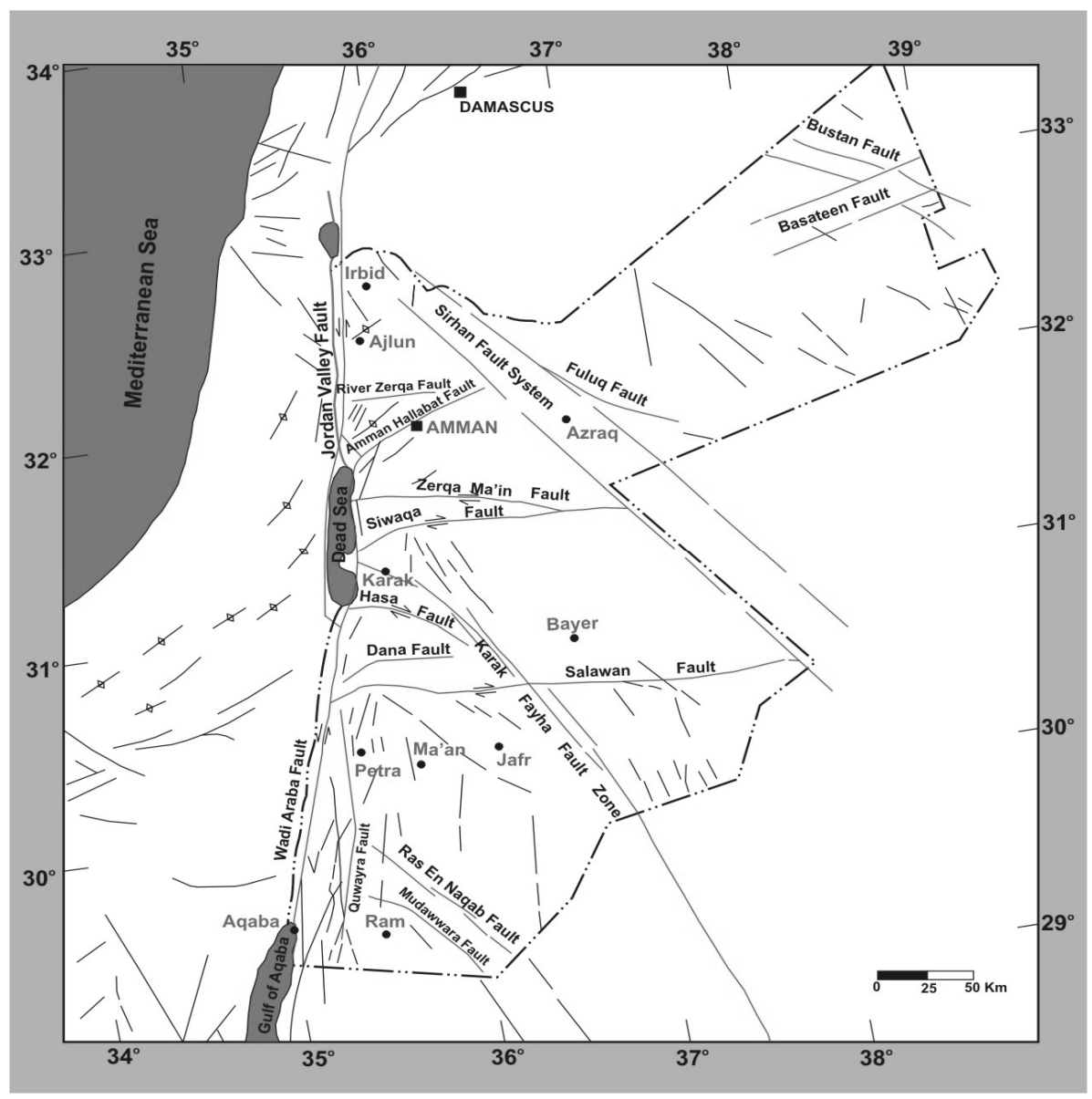

Figure 6. Structural map of Jordan, showing the distribution of the main structures [27].

Ramtha syncline and depressions as Jafer-Azraq-Wadi Eserhan.

The main regional structure in Jordan is Wadi ArabaDead Sea Transform fault, which is a part of the long rift that extend from east Africa a cross Gulf of Aden-Red Sea and extend to south Turkey. The Wadi Araba-Dead Sea Transform fault extends $360 \mathrm{~km}$ long and the main hypothesis of the origin of this fault is related to vertical and horizontal displacements [27].

\section{THE MINERAL INDUSTRY IN JORDAN}

In Jordan, the production of industrial minerals and rocks that belong to nonmetallic origin has a basic role of the country economy. Huge reserves of these materials have many applications such as fertilizers, chemicals, buildings, and decorations. Most of these rocks, such as phosphates, lie near the surface, and this would be reflected on the advantage of low cost of production in most mining activities in Jordan.

The recent mining history in Jordan was established by Jordan Phosphate Mines Company (JPMC) since 1935. Prospecting of minerals and exploration programs in Jordan continued for many years after the first exploi- tation of the phosphate rocks, followed by exploration of copper, manganese, limestone, travertine, gypsum and clay minerals. In the last few years Natural Resources Authority (NRA) worked intensively to attract foreign companies to continue the exploration work and commercial exploitation for metallic minerals such as copper and manganese in addition to the precious metals such as gold within Wadi Araba area.

The mining sector in Jordan can be subdivided into mineral extraction industries and mineral manufacturing industries. Phosphate, potash, salt, calcium carbonate, treated zeolite, treated silica, travertine, other quarries and mines products are part of extractive industries, while the mineral manufacturing industries composed of two branches: the chemical industries (fertilizers, chemical acids, aluminum fluoride, quick and quenched lime) and the construction materials industries (white cement, rock wool, building materials, china ceramic tiles and sanitary ware) [38]. The mining sector revenues contribution to the Gross National Product (GNP) has fluctuated between 11.5\% in 2005 and 8.5\% in 2009 (Figure 7 ). The most important mineral products share to the GNP in 2009 were potash (2\%) followed by phosphate 
(1.7\%) (Figure 8). Mineral products as percentage of mining sector production in Jordan during 2009 are shown in Figure 9. Potash, phosphate and cement form more than $60 \%$ of total mining production in Jordan. Regarding the recent reports of the NRA during 2008 and 2009, more than 1550 exporting permissions were issued, the most exporting permissions for different mineral ores focused on oil shale, phosphate, limestone, calcium carbonate, dolomite, silica (glass sand), basalt aggregates, feldspar, marble, clay (kaolin and bentonite), gypsum, travertine, zeolites, volcanic tuff, crushed aggregates and salt [38].

The distribution of metallic and non-metallic minerals in Jordan is shown in Figure 10. The industrial minerals and rocks are discussed here in accordance to their geological widespread and their commercial value for the country.

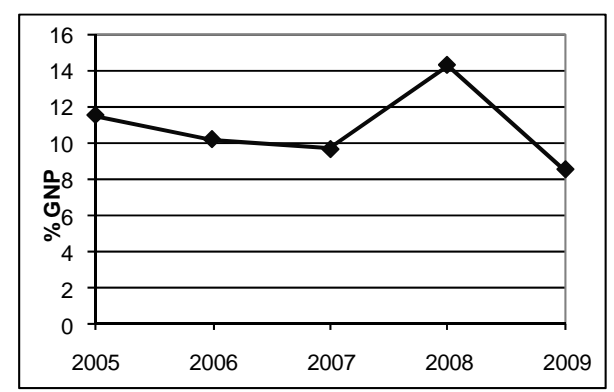

Figure 7. Mining sector revenues as \% of GNP during 2005-2009 [38].

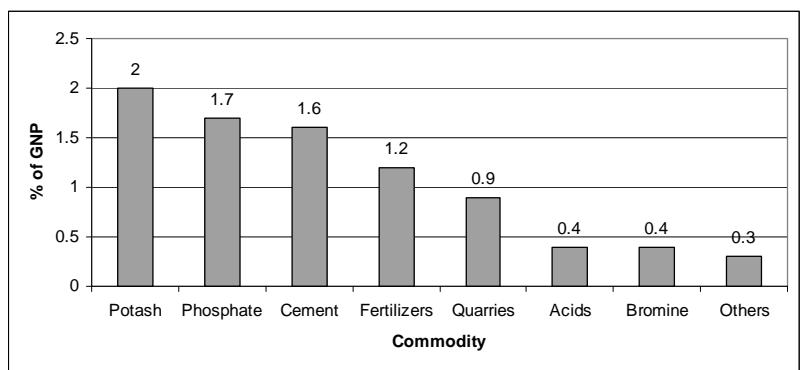

Figure 8. Most important mineral products as \% of GNP during 2009 [38].

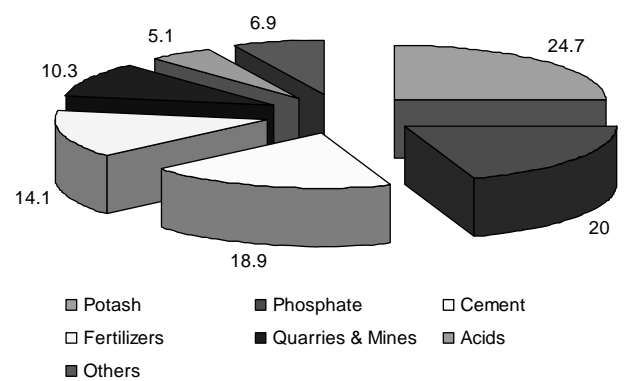

Figure 9. Mineral products as \% of mining sector during 2009 [38].

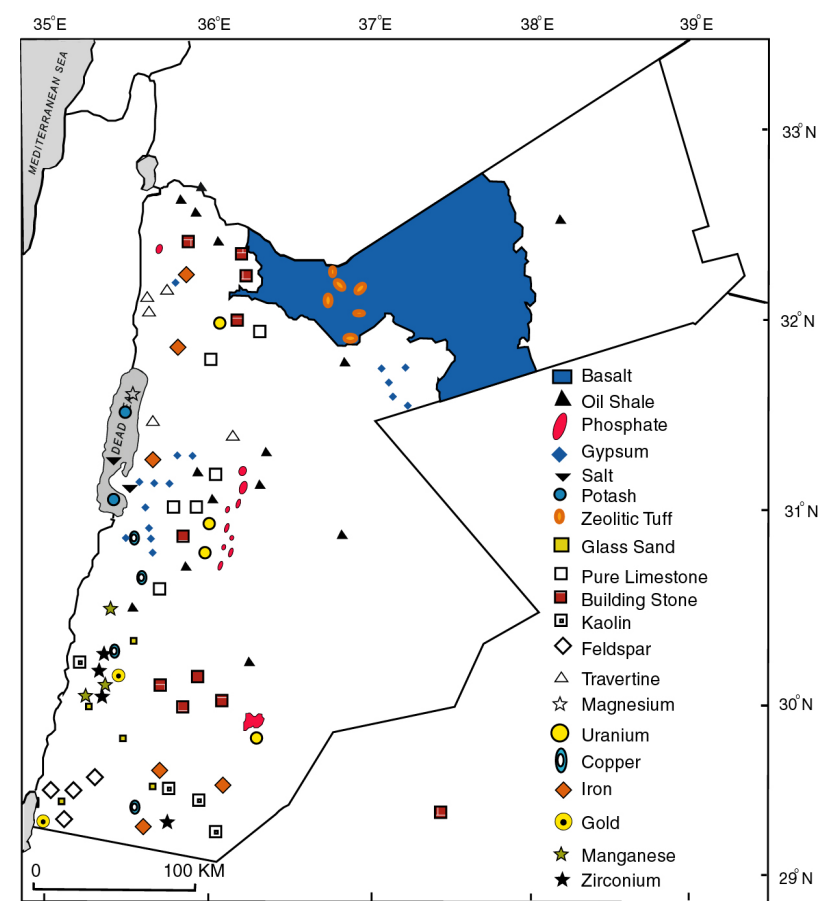

Figure 10. Distribution of metallic and non-metallic minerals in Jordan.

\section{NON-METALLIC MINERALS}

\subsection{Phosphate}

The economic phosphate deposits are restricted to the Campanian-Maastrichtian part of the upper Cretaceous sequence that was deposited in shallow marine environment. The Jordanian phosphate is mainly composed of cryptocrystalline apatite and the major mineral is francolite [27]. The Tri-Calcium-Phosphate (TCP) content is between $40 \%$ to $75 \%$ [39].

The Jordan Phosphate Mines Company (JPMC) commenced its phosphate mining activities in Al Ruseifa area in 1935. In 1989, JPMC started production in Eshidiya which is located in the south of Jordan, approximately $125 \mathrm{~km}$ north-east of the port at Aqaba. Eshidiya mine hosts the largest high-grade reserve in Jordan and contribute to $64 \%$ of JPMC total production (Figure 11). The total phosphate production in 2011 was about 7.6 Mt in which 3.6 Mt traded globally for exports [39].

The NRA has extensively studied the limestone resources from different localities in Jordan. Most importantly that of Haddadin and Teimeh [40]; Technostone [41]; El-Hiyari [42]; Tarawneh [43]; Barjous [44]; Basem [45]; Tarawneh and Abu Gubeh [46]; Abu Salah, et al. [47] and Mdanat and Ghannam [48].

\subsection{Limestone}

The limestone deposits are distributed from Irbid at the north to the Ma'an at the southern part of Jordan, and 
belong mainly to upper Cretaceous age and partially to Eocene age [45]. Limestone is extensively used as building stone. Currently, pure limestone is mined, produced and exploited for the use of white cement, magnesia, and calcium carbonate industries. The local consumption may reach 450,000 ton/year.

\subsection{Dolomite}

Dolomite occurs in different stratigraphic levels and is generally associated with limestone. In general, it can be found in the Burj Dolomite Shale Formation of Cambrian age and in Naur, Hummar and Wadi Esir formations (Turonian). In some areas there are indicated approved reserves as in the area between Wadi Isal and Ahemir Iasal of $62 \mathrm{Mt}$ and at Al-Haditheh area of $20 \mathrm{Mt}$ [49]. Chemical analysis by NRA indicates that $\mathrm{MgO}$ reaches up to $18.98 \%$ (Figure 12).

\subsection{Marble}

Marble does not occur in exploitable quantities in Jordan. However, thermo-metamorphosed limestone occurs as lenses and irregular bodies within the bituminous facies in the upper part of the Muwaqqar Chalk Marl Formation. They are exposed in areas of up to $20 \mathrm{~km}^{2}$ described by Nassir and Khouri [50]. According to investigations of NRA, exploitable marble occurs in areas between Daba'a and Qatrana, south of Amman [44]. Jordanian marble is hard, dense and partially recrystallized and strongly affected by tectonic movements. It is varicolored by iron oxides, bituminous matter and traces of

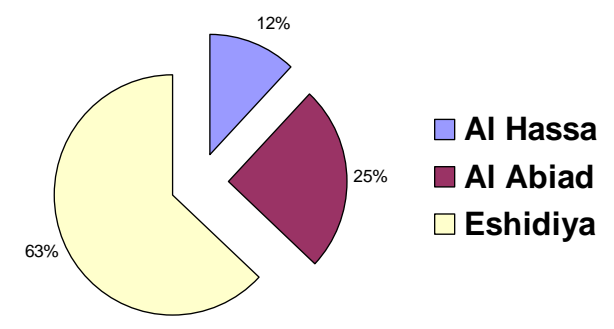

Figure 11. Total JPMC mines production in 2011 (Total production $7.60 \mathrm{Mt}$ ) [39].

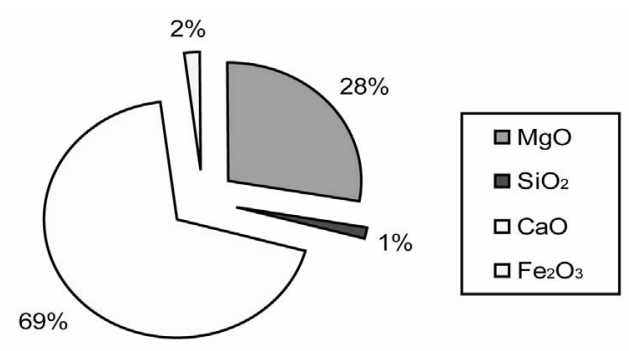

Figure 12. Chemical composition of the dolomite rocks located between Wadi Isal and Ahemir Iasal [49]. chromium, nickel, vanadium and uranium bearing minerals [50]. Small companies produced small quantities for local consumption from some quarries.

\subsection{Travertine}

Travertine in Jordan located near active and extinct thermal springs along the east side of the Dead Sea-Jordan Rift. The largest deposits belong to the lower Pleistocene. The travertine is between 30 - 40 m thick and intercalates locally with thin layers of pebbly sandstone [28]. Different types of travertine are distinguished as yellowish and white. Travertine can be utilized as an attractive colored and textured decoration stone. Exploitation of this deposit commenced in 1980. Since 1999, Travertine Company PLC (Travco) was established with the purpose of exploiting and processing the massive Travertine stone outcrops in the Jordan Valley, with an invested capital of US \$6.5 million.

\subsection{Chalk}

Chalk deposits are mainly found within the Muwaqqar Chalk Marl and Wadi Shallala formations (MaastrichtianMiddle Eocene age). The main Locations of chalk occur in Al-Umary-Dahikiya, Wadi Al-Ghadaf, Qaser AlHarrana and Wadi Al-Dha'abi. Huge reserves of these deposits reported in Azraq basin [51-55].

Many boreholes were drilled and tested by the NRA during 2002. Mt of reserves was estimated in the Azraq basin areas [56]. The $\mathrm{CaO}$ in these localities is between $38.9 \%$ and $53.15 \%$ and the brightness is between $74.8 \%$ and $85 \%$ (Table 1). High quality of chalk is used in paint, agriculture and cement industry.

\subsection{Silica Sand (Glass Sand)}

White pure silica sand deposits are exposed in Jordan on the surface. They are related to Disi Sandstone Formation of Early Ordovician age and Kurnub Sandstone Formation of Lower Cretaceous age. Theses deposits are exposed in south of Jordan (Ras En Naqb, Qa'a Ed Disi and Al Jayoshia). Ala'li [57] studied in details the most specific properties of the sand and gave an evaluation for the beneficiation of silica sand and kaolinitic sandstone

Table 1. Chemical and physical properties of Jordanian chalk at the main localities [55].

\begin{tabular}{ccc}
\hline Location/Area & CaO (\%) & Brightness (\%) \\
\hline Al Umary-Dahikiya & $38.90-49.60$ & $74.80-81.70$ \\
Wadi Al-Ghadaf & $43.60-52.60$ & $79.50-81.40$ \\
Qaser Al-Harrana & $47.90-52.60$ & $76.60-83.50$ \\
Wadi Al-Dha'abi & $51.59-53.15$ & $76.60-85.00$ \\
\hline
\end{tabular}


in south of Jordan. Huge reserves of billion of tones in these localities are indicated by the NRA. More than five companies in the mentioned area produce glass sand for manufacturing industry [2]. The $\mathrm{SiO}_{2}$ in Ras En-Naqab area reaches up to $98.7 \%$ (Table 2).

\subsection{Diatomite}

The NRA has discovered the diatomite in the mud flats of Azraq area in 199. The exploration revealed that the diatomite occurs in two beds that are composed mainly of diatomite and clay minerals. Detailed physical and chemical properties on diatomite were evaluated by Alali $[58,59]$. There is no current mining production of this ore. The content of $\mathrm{SiO}_{2}$ from Azraq area is between $41 \%$ and 70.7\% with minor and trace oxides (Figure 13) [59].

\subsection{Tripoli}

Tripoli in Jordan occurs in the lower levels of Amman Silicified Limestone Formation (upper CretaceousCampanian age). There are many occurrences of tripoli, mainly in east of the Jordan Rift, Karak area and north of Wadi Araba. Four major tripoli occurrences in Karak area have been investigated by the NRA in detail. The reserves of the four selected deposits amount of $2.4 \mathrm{Mt}$ [28]. The $\mathrm{SiO}_{2}$ content is between $92.45 \%$ and $97.0 \%$,

Table 2. Chemical analysis (oxides \%) of silica sand samples from Ras En-Naqb [57].

\begin{tabular}{cc}
\hline Component & Average \\
\hline L.O.I & 0.61 \\
$\mathrm{SiO}_{2}$ & 97.6 \\
$\mathrm{Al}_{2} \mathrm{O}_{3}$ & 1.31 \\
$\mathrm{Fe}_{2} \mathrm{O}_{3}$ & 0.028 \\
$\mathrm{TiO}_{2}$ & 0.18 \\
$\mathrm{CaO}$ & 0.06 \\
$\mathrm{MgO}$ & 0.01 \\
$\mathrm{~K}_{2} \mathrm{O}$ & 0.01 \\
$\mathrm{Na}_{2} \mathrm{O}$ & 0.01 \\
\hline
\end{tabular}

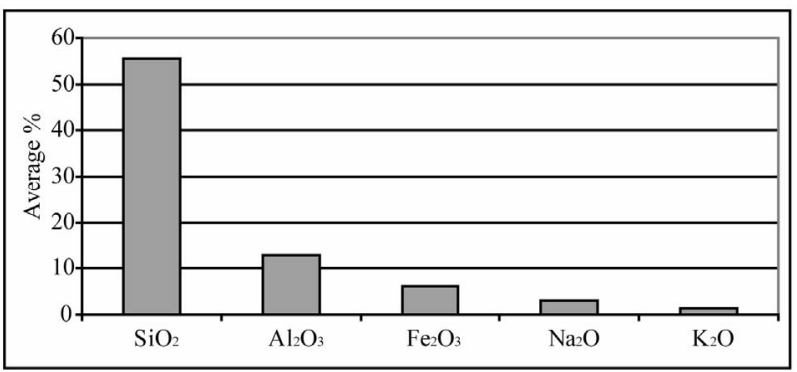

Figure 13. Chemical analysis of Azraq diatomite [59]. with some traces of oxides (less than $2 \%$ ).

The tripoli origin is explained as a result of leaching of the carbonate content of the original sediment and replacement by silicon dioxide from migration solutions [35].

\subsection{Clay (Kaolin)}

The most dominant localities of kaolin deposits with an Ordovician age are exposed in the southern part of the country (Baten el Ghoul, Al Mudawara and Al Hiswa areas) [60].

The mineralogical and industrial characteristics of Batn El Ghoul clay deposits were studied by Khouri and El Sakka [60]. The NRA exploration during 1996-2004 indicated huge reserves in southern Jordan. Mineral processing methods including beneficiation of Kaolinite deposits have been studied in detail by Ala'li [57]. Currently five companies exploit kaolin deposits as a raw material. Most of the kaolin extracted is used in cement, ceramics companies, clay bricks factories, and paint industries.

\subsection{Clay (Bentonite)}

Detailed studies of bentonite deposit in Q'a Al Azraq can be found in the work of Haddadin [61] and Jasser [62].

Khouri [63] identified a smectite mixed-layer clay and kaolinite in which quartz, feldspar and calcite are present as impurities at the same localities. Intensive exploration on bentonite has been continued by the NRA during 1991-1993. The results can be found in the work of Ibrahim [64] and Al'ali and Abu Salah [65]. Applications and uses of bentonite as binding agents in foundry sand are reported in the work of Dweiri and Salam [66].

Nawasreh [67] studied the main properties of the bentonite as well as its specific surface area, oil absorption, water absorption, attenuation of heavy metals and bleaching capacity of edible oil after acid activations. The NRA exploration indicated approved reserves in Ein al Bayda area of about 105 Mt [2]. Jordanian bentonite composition from Azraq is slightly comparable with that of Wyoming bentonite (Figure 14).

\subsection{Gypsum}

Gypsum deposit belong to Triassic, upper Cretaceous and Quaternary ages [68-70]. The geological reserves of Jordanian gypsum are estimated in million of tons with thickness ranges from $1 \mathrm{~m}$ to $60 \mathrm{~m}$ [41]. Due to high demand in the Arab countries and international markets for a quality plaster, the production of this material is highly required.

The Public Mining Company produces gypsum from River Zarqa Basin, Malih and Barbaiteh (south Jordan) 
for Jordanian cement factories and to the private sector. An Arabian company with 3 millions dollars investment has been established to manufacture gypsum products.

The chemical analysis of Jordan's gypsum from different localities is shown in Table 3 [68]. Gypsum in Jordan is used mainly for cement, building construction, chemical, medical and ceramics.

\subsection{Granite}

Acidic granite belongs to the Arabian Nubian Shield, which consists of Precambrian crystalline igneous rocks, extending at the southern part of Jordan forming its basement rocks $[1,26,37,71]$. The rocks were affected by several deformation phases, which resulted in an intense fracturing and deep weathering. Intense erosion has left very wide valleys and mud flats, exposing, at the same time, the granites which were least affected by tectonics. Through the ages, the basement has been peneplaned and covered by thick deposits of Cambrian and Ordovician rocks [28]. There are three deposits sites, with different granites, located in the south of Jordan. Granite Reserves within the studied areas are unlimited and it is mainly used for building decoration [2].

\subsection{Feldspar}

Feldspar belongs to the granitic rocks of Abu Jadda granite and the Imran Monozogranite of Aqaba complex (582 - $589 \mathrm{Ma}$ ) [37]. Investigations on feldspar occur-

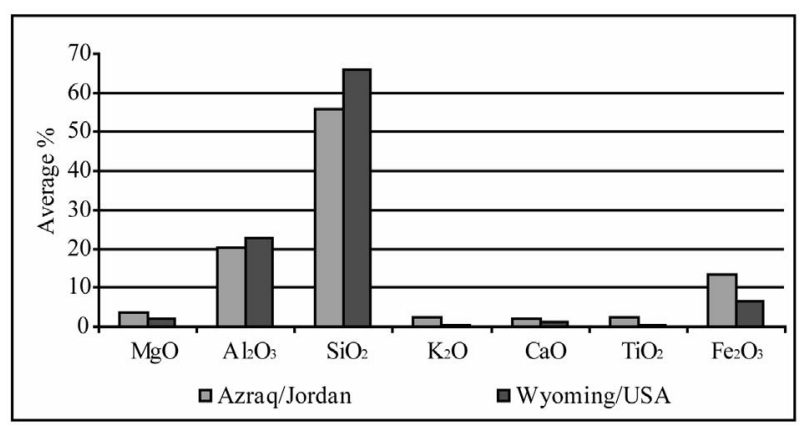

Figure 14. Chemical comparison (\%) between Jordanian bentonite and Wyoming bentonite [67].

Table 3. Chemical analysis of some selected samples of Jordan Gypsum [68].

\begin{tabular}{ccc}
\hline Area & $\mathrm{SO}_{3}(\%)$ & $\mathrm{CaO}(\%)$ \\
\hline River Zarqa Basin & $40-47$ & $31-34$ \\
Central and southern Jordan & $37-46$ & $25-35$ \\
Azraq & $42-45$ & $32-35$ \\
Wadi Al-Dahel & $36-52$ & $29-39$ \\
Jabal Bani-Hamida & $45-60$ & $32-36$ \\
\hline
\end{tabular}

rences in Southern part of Jordan are reported in Pical and Gharaybeh [72], Hakki [73] and Haddadin and Barakat [74]. Feldspar reserves are estimated around 115 Mt. Barjous [75,76] studied the possibility to concentrate feldspar and the results were promising. Due to the importance of feldspar for industrial application in glass and ceramic industries, the NRA has started an exploration project for feldspar in Wadi Saader Mulghan area and other areas north of Aqaba [2].

\subsection{Basalt}

Basalt is a volcanic rock which was derived from magma and spread over different areas in Jordan. The most important locations are in northeast Jordan, which belong to Harrat As Sham Basaltic Super Group which covers more than $11,000 \mathrm{~km}^{2}$ in this part of the country. Jordanian basalt belongs to Neogene-Quaternary age [77]. Basalt also occurs in central Jordan (Mujib and Shihan areas), southwestern Jordan along the rift (Main area) and southern part of the country as basaltic flows and volcanic centers in Tell Burma and Jabel Uneiza (Ma'an area). Basalt can be used in many industrial applications such as: rock wool, pipes, moulds, and as construction materials [78,79]. The mineral composition of the basalt is made of plagioclase, pyroxene, olivine, iron oxides and secondary minerals of calcite and zeolites [80]. The silica content of Jordanian basalt may exceed $40 \%$ (Figure 15) [78]. The main domestic uses of basalt in Jordan are in the wool rock industry.

\subsection{Zeolites}

Zeolites are widespread in Jordan and they occur as a cementing material in many volcanic centers. Zeolitic tuffs are also located at many volcanic centers in the central and southern parts of the country. Zeolites minerals have been discovered for the first time at Jabal Al Aritayn in northeast Jordan by Dwairi [81]. Detailed studies by Ibrahim [82] and Dwairi [83] indicate that the zeolites minerals were formed from alteration process of volcanic glass.

Zeolite minerals like phillipsite, chabazite and faujasite are the most abundant minerals found in the Jorda-

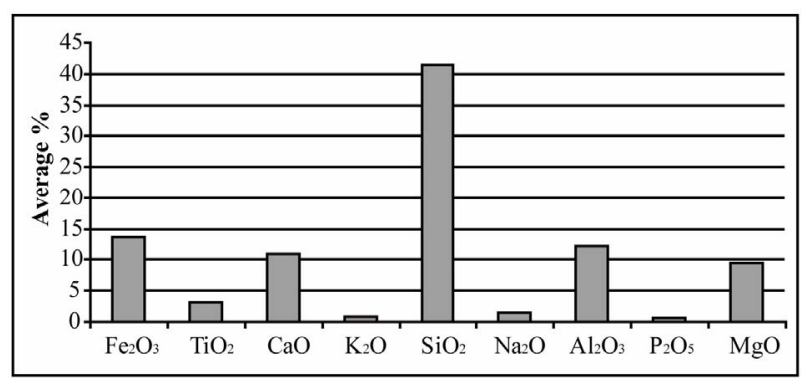

Figure 15. Chemical analysis of Azraq basalt [78]. 
nian volcanic tuff $[84,85,79]$.

Mineralogical studies by Ibrahim [82] indicated that zeolitic content in these tuffs varied from $20 \%$ to $70 \%$, while Gharir [86] through using simple mineral processing techniques, discovered that the zeolite concentrates with grades up to $90 \%$ were achieved. Huge geological reserves of million of tones were estimated by the NRA in many localities in northeast and southern parts of Jordan. The chemical composition of Jordanian zeolitic tuff from different localities in Jordan is quietly comparable (Figure 16) [82].

Mining activities of Zeolitic tuff production in Jordan started in 1998. The total output in 2002 was 4500 tons. Zeolitic tuff is produced by three companies that are located in northeast part of the country. One of the biggest companies, such as Green Technology started to pro duce different grades of zeolites.

Total domestic consumption was estimated to be 3500 tons. The majority of this consumption can be used in agricultural applications, soil conditioner and amendment, controller of fertilizers, cat litter and in sport courts and gardens.

\subsection{Zircon}

Geological prospecting of NRA on radioactive and heavy minerals, including zircon and associated sandstone rocks, were focusing on the middle member of Dubaydib Sandstone Formation (DB2) of Middle Ordovician age which composed mainly of quartz, feldspar and heavy minerals of zircon, rutile, brookite, epidote and monazite [87]. Masri [88] carried out a geological mapping of Wadi Al-Mezrab area at a scale 1:10,000 which encompassed the area of zircon deposits. In 1997, the NRA started an exploration program for zircon and heavy minerals. The study included drilling 39 boreholes and 7 trenches, sampling and reserve determination. In 1999, many samples were sent to the international laboratories for analysis. Results gave good results about the presence of zircon and rare earth elements (REE). In 2002, bulk sample (500 kg) was prepared and sent to Egyptian Geological Survey laboratories for mineral processing.

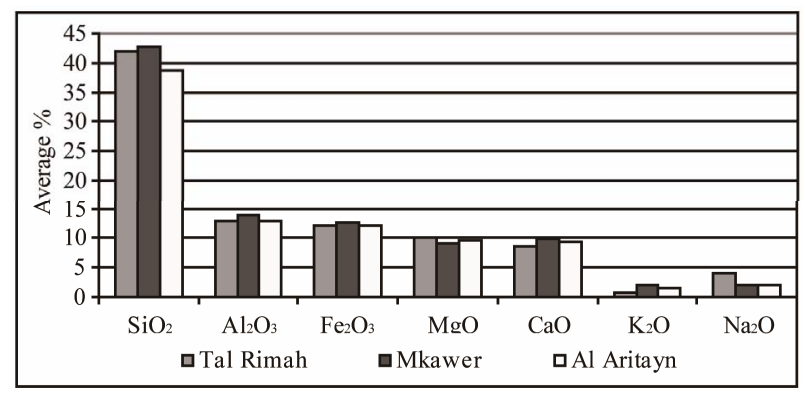

Figure 16. The chemical composition (in \%) of the Jordanian zeolitic tuff [82].
The result of this study indicated that zircon could be concentrated with $80 \%$ purity. Chemical properties of Jordan zircon are shown in Table 4 [89].

In 2004, NRA carried out an exploration program in new localities. The estimated reserve in one locality at Wadi Al-Mezrab area is about 96,000 metric tons. Zircon minerals are currently under attention of Jordanian Atomic Agency which are responsible of exploration and prospecting of radioactive elements in Jordan.

\subsection{Uranium (U) and Thorium (Th)}

The uranium and thorium in Jordan are mainly associated with phosphate and sandstone rocks. The Al Hasa Phosphorite Formation which belongs to the upper Cretaceous is the source of $\mathrm{U}$, ranging in contents from 40 ppm to $250 \mathrm{ppm}$ [28]. New exploration by Jordanian Atomic Agency indicates more than 60,000 tons of uranium ore.

The $\mathrm{U}$ and Th in Jordan also occur in acidic granitic rocks and reach up to $400 \mathrm{ppm}$ and $75 \mathrm{ppm}$ respectively. The Paleozoic sandstone rocks in southern part of Jordan contain $400-460 \mathrm{ppm} \mathrm{U}_{3} \mathrm{O}_{8}$ and $30-370 \mathrm{ppm} \mathrm{ThO}_{2}$. The geological chances for the prospecting and exploration of $\mathrm{U}$ and $\mathrm{Th}$ in phosphate rocks and in sandstone rocks are considered to be variable. Uranium reserves proved large enough to make mining commercially viable. Jordan has ordered intensified efforts to launch a civilian nuclear program. Nowadays Jordan is conducting an intensive uranium exploration program working with major partners like Areva and Rio-Tinto, with a budget that will exceed \$16 million in 2011. Reserves of more than 80000 tons of $U$ were approved by recent exploration from different mining companies in many parts of the country.

\section{METALLIC MINERALS}

\subsection{Copper}

Copper mineralization of commercial value occurs within an approximately $70 \mathrm{~km}$ long and $15 \mathrm{~km}$ wide area along the eastern side of the central Wadi Araba from the southern end of the Dead Sea to Beir Madkour. Copper ore occurs within two formations, Wadi AbuKhusheiba Sandstone Formation, and the Burj-Dolo-

Table 4. Chemical properties of Jordanian zircon [89].

\begin{tabular}{ccc}
\hline Mineral & Composition & Grade \\
\hline Zircon & $\mathrm{ZrSiO}_{4}$ & $0.67 \%-3.75 \%$ \\
Cerilium & $\mathrm{Ce}$ & $499-2168 \mathrm{ppm}$ \\
Lanthanum & $\mathrm{La}$ & $224-1065 \mathrm{ppm}$ \\
Titanium & $\mathrm{TiO}_{2}$ & $1.61 \%-4.91 \%$ \\
\hline
\end{tabular}


mite-Shale Formation [22]. Both are of Cambrian age and striking in North-South direction. Copper with less commercial value also occurs in basic to intermediate dikes within the Precambrian igneous rock complex. Detailed studies on copper are reported in Sunna [90], Nimry [91], Hagen [92] and Rabba [93]. According to these studies, the mean average content of commercial copper in the promising areas is from $0.5 \%$ to $1.36 \%$. The major areas of copper deposit are in: 1) Khirbet El-Nahas (Wadi El-Jaryia) area which is located in the central part of Wadi Araba within the Feinan area, and covers $5 \mathrm{~km}^{2}$; 2) Feinan area (Wadi Khalid, Dana and Ratyia) which is located in the central part of Wadi Araba, and covers $12 \mathrm{~km}^{2}$; 3) Abu-Khusheiba area which is located in the Southern part of Wadi Araba, $100 \mathrm{~km}$ north of the Aqaba, and covers $28 \mathrm{~km}^{2}$. Reserves estimates (within the study areas): Wadi El-Jaryia 0.6 million ton, Feinan 19.8 million metric ton and Abu-Khusheiba 8 million metric ton $[94,95]$. Copper is still not touched by mining companies in Jordan and no mining activity has taken place.

\subsection{Manganese}

Manganese ore is located in the east side of northern Wadi Araba (Wadi Dana and Finan areas). The major ore bodies occur as strata bound elongated lenses and layers of nodular and compact ore masses in the uppermost part of Burj Dolomite Shale Formation (Cambrian age). The ore origin is explained as being of hydrothermal origin [96]. Manganese is composed of nodular habit, heavy and massive. The compact $\mathrm{Mn}$ ore is up to $3 \mathrm{~m}$ and coming also as disseminated in sandstone rocks. Mn content in the rocks is between $35 \%$ and $50 \%$ [97]. The main mineral of the ore is pyrolusite $\left(\mathrm{MnO}_{2}\right)$, with secondary and accessory minerals. An estimated reserve by the NRA is up to $5 \mathrm{Mt}$ [91]. No mining activities in Jordan of the manganese ore has taken place till this moment.

\subsection{Iron}

Iron ore occur within the massive and chalky limestone of the upper Cretaceous in Warda area, near Burma village (Jarash area). The origin of the iron ore is due to hydrothermal, probably, late magmatic, epithermal with metasomatic replacement of the carbonate by hematite. The ore thickness is between 0.8 and $9.80 \mathrm{~m}$. The average of $\mathrm{Fe}_{2} \mathrm{O}_{3}$ content is $67.9 \%$. The estimated reserves amount to 561,000 tons of ore [28].

Iron oxides with no commercial value occur in different stratigraphic level in Jordan, particularly in sandstone rocks. Impregnation of iron oxides in the sandstone is well known in southern part of Jordan. Chemical analyses of ferruginous sandstone indicate that the $\mathrm{Fe}_{2} \mathrm{O}_{3}$ content ranges from $4.24 \%$ to $44.46 \%$ [98].

\subsection{Gold}

Gold occurrences belong to the Aheimer volcanic suite, which is a part of the Araba complex. The suite is composed mainly of effusive and intrusive quartz and quartz feldspar porphyry with andesite rocks. Intensive geochemical exploration revealed that the gold mineralization is hosted in narrow veins with up to $1 \mathrm{~m}$ in width extending over several kilometers within the Ahiemer suite. Chemical analyses by the NRA revealed that the gold content in this vein reach up to $15 \mathrm{~g} / \mathrm{t}$ [2], while in placer deposits, gold content reach up to $40 \mathrm{~g} / \mathrm{t}$ [99]. Currently, the NRA is planning to explore/exploit gold and associated minerals in south Jordan through a production sharing agreement with local and international exploration companies.

\section{OTHERS}

Other less important mineral resources include anhydrate, barite, sulfur, semi-precious stones, trace and rare earth elements (REE). Anhydrate has been described from Triassic sequence near Wadi Zarqa River. Most of the anhydrate is not in commercial interest. Barite appear within sandstones of the Kurnub Sandstone Formation (Cenomanian age); in limestone and marl of the Turonian-Santonian age, and filling of fault zones and fissures in limestone or in marl and bituminous marl (Eocene age). The origin of barite is due to hydrothermal solutions. Sulfur occurs in bituminous marly limestone (oil shale) of upper Cretaceous and lower Tertiary age; as native element in the Lisan Marl of Pleistocene age; in tar sand (lower Cretaceous and Cambrian rocks) and in heavy oil and asphalt. The Jordanian oil shale from Muwaqqar chalk marl formation deposited during in the shallow continental shelf of Tethys Ocean. Paleo-productivity and bottom water conditions are among the main factors controlling their formation [100,101]. The indicated oil shale reserve is up to 37 billion tons [102].

Occurrences of semiprecious stones are not widely distributed throughout the country and they consist mainly of agate which is found in some vugs and filling of joints and cavities in silicified concretion in the upper Cretaceous rocks and Eocene rocks. The agate with low quality is typical for their occurrences. Silicified wood in the upper Cretaceous formations along the Ras Enqab Escarpment and various cryptocrystalline silica minerals could include agate and opal, but not with commercial interest. Cu-hydrocarbonate and silicates of malachite, azurite, chrysocolla and plancheite (Cambrian age) are worth mentioned as possible minerals for the manufacture of gemstones. Cutting and polishing tests have shown that these minerals are suitable for using as gemstones [28]. Garnet associated with biotite-garnet-schist of metamorphic rocks are scattered throughout these 
rocks and also found in sand and gravel of the Wadi Abu Barqa and Wadi Huwar at Gharandal area of Wadi Araba [28].

\section{CONCLUSIONS}

The mineral industry in Jordan has a long and a prominent history and its current and future prospects and potentials seem encouraging. Jordan has provided continuous efforts to promote its mining sector which contributed to around 8.5\% to its Gross National Product (GNP) in 2009. Jordan has huge reserves of phosphate, glass sand, building stones, oil shale, dolomite, travertine, clays, gypsum, zeolitic tuff in addition to a promising prospecting of metallic minerals such as copper, manganese, iron and gold. Radioactive elements like uranium, thorium, and zircon are present in good quantities. The Natural Resources authority (NRA) is the main regulator and instigator of most of the mining activities in the country. Its role is vital in exploration and prospecting of ores and minerals. One of the main targets of the NRA is to provide the interested companies with all the required information, studies and maps to help them in carrying out their exploration and extraction operations. Till now, the main projects have come up with around twenty non metallic minerals and four metallic minerals. The paper has discussed brief descriptions of these minerals along with their chemical and mineralogical properties in addition to their production, and reserves statistics. The country remains under explored and a committed, systematic exploration approach which will undoubtedly lead to significant new discoveries.

\section{ACKNOWLEDGEMENTS}

The authors are thankful for the very kind assistance of the Natural Resources Authority staff, and all colleagues of the NRA for their support and encouragement during the preparation of this work. Thanks also are extended to the anonymous reviewers for their comments.

\section{REFERENCES}

[1] Bender, F. (1974) Geology of Jordan. Contribution to the regional geology of the world. Gebrueder Borntraeger, Berlin.

[2] Natural Resources Authority (2009) Mining sector performance during 2009 compared with the last four years: Investment and international cooperation division. The NRA Annual Report, Amman.

[3] Central Bank of Jordan (2009) Monthly statistical bulletin. Central Bank of Jordan, Amman.

[4] Lartet, L. (1869) Investigation on the geology of Palestine and neighboring countries such as Egypt and Arabia. Annual Geological Science, 1, 149-329.

[5] Blanckenhorn, M. (1903) Die mineralschatze Palestine mitt. undnachr des deutch. Geological Report of Palestine, Jerusalem, 65-70.

[6] Blanckenhorn, M. (1914) Syrian, Arabien und Mesopotamien: Handbuch der regionalen geologie. Heidelberg, 5, 23 p.

[7] Cox, J. (1925) A bjocian-bathonian outcrop in the Jordan valley and its molluscan remains. Annual Magazine Natural History Series, 9, 69-181.

[8] Cox, J. (1932) Further notes on the Transjordan triassic. Annual Magazine Natural History Series, 10, 93-113.

[9] Blake, G. (1930) Geological map of Palestine, scale 1:250,000. Geological Survey of Palestine, Jerusalem

[10] Blake, G. (1936) The stratigraphy of Palestine and its building stones. Jerusalem Printing and Stratigraphy Office, Jerusalem.

[11] Ionides, G. and Blake, G. (1939) Report on the water resources of Transjordan and their development. Incorporating report on geology, soil, mineral and hydrogeological correlations. Crown Agents for the Colonies, London.

[12] Picard, L. (1943) Structure and evolution of Palestine. Hebrew University of Jerusalem, Jerusalem.

[13] Shaw, S.H. (1947) Southern Palestine geological map on a scale of 1:250.000 with explanatory notes government. Printer Government of Palestine, Jerusalem.

[14] Quennell, A. (1951) The geology and mineral resources of (former). Transjordan: Colonial Geology and Mineral Resources, 2, 85-115.

[15] Quennell, A. (1956) Geological map of Jordan (east of the rift valley 1:250,000). Department of Lands and Survey, The Hashemite Kingdom of Jordan, Amman.

[16] Wetzel, R. and Morton, D.M. (1959) Contribution to the geology of Transjordan. Notes and memoirs on the Middle East: No. 71959, 95-191.

[17] Burdon, D.J. (1959) Handbook of the geology of Jordan: To accompany and explain 1:250,000 geological map of Jordan east of the rift by A. M. Quennell. Government of the Hashemite Kingdom, Amman.

[18] Masri, M. (1963) Report on the geology of the AmmanZerqa area. Unpublished Report, Central Water Authority, Amman.

[19] MacDonald, M. and Partners, M. (1965) East water resources. Hydrological survey of the Madaba-Ma'an area. Central Water Authority, Amman.

[20] Bender, F. (1961) Report on the first geological reconnaissance mapping the area of the copper ore bearing sandstone. The NRA, Amman.

[21] Bender, F. (1968) Geologie von Jordanien. Bietrage zur regionalen geologie der erde. Geological Survey of Germany, Berlin.

[22] Bender, F. (1975) Geology of the Arabian Peninsula. US geological survey professional paper 560-I, Jordan.

[23] Parker, D. (1970) The hydrology of the mesozoic-caniozoic aquifers of the western highlands and Plateau of East Jordan: (4 Vols.). Unpublished Technical Report, Rome.

[24] Phoenix Corporation (1980) A comprehensive airborne 
magnetic/radiation survey of the Hashemite Kingdom of Jordan. Unpublished Report, The NRA, Amman.

[25] Hagen, D. (1980) Geochemical prospecting in target areas of the Wadi Araba: Follow up investigations on copper anomalies in Wadi Abu Khusheiba-Wadi Araba, Jordan: Hannover, Bundes. F. Boden. Unpublished Report, the NRA, Amman.

[26] Abed, A.M. (1982) Geology of Jordan. Al Nahda Al Islamiah Library, Amman.

[27] Abed, A.M. (2000) Geology of Jordan. Jordanian Geologists Association, Amman.

[28] Ajamieh, M.A., Bender, F.K. and Eicher, R.N. (1988) Inventory evaluation development program. The NRA, Amman.

[29] Powell, J. (1988) The geology of Karak. The NRA, Amman.

[30] Powell, J. (1989) Stratigraphy and sedimentation of the phanerozoic rocks in central and south Jordan. Ram and Khreim Groups, The Natural Resources Authority Bulletin, Amman.

[31] Powell, J. (1989) Stratigraphy and sedimentation of the phanerozoic rocks in central and south Jordan. Kurnub, Ajlun and Belqa Groups, The Natural Resources Authority Bulletin, Amman.

[32] Abed, A.M. and Omari, K. (1994) Role of industrial rocks and minerals in the development of Jordan, In: Mathers, S.J. and Notholt, A.J.G., Eds., Industrial Minerals in Developing Countries, AGID Report Series Geosciences in Intern, Development 18, British Geological Survey.

[33] Khoury, H.N. and Ibrahim, K. (2000) Mineral resources of the Badia region, north east Jordan. Higher Council for Science and Technology, Amman.

[34] Ibrahim, K., Rabba, I. and Tarawneh, K. (2000) Geological and mineral occurrences map of the northern Badia region, Jordan, scale 1:250 000. The Higher Council for Sciences and Technology and the Natural Resources Authority, Amman.

[35] Khoury, H.N. (2006) Industrial rocks and minerals in Jordan. 2nd Edition, The University of Jordan, Amman.

[36] Khoury, H., Al Houdali, H., Mubarak, Y., Al Faqir, N., Hanayneh, B. and Esaifan, M. (2008) Mineral polymerization of some industrial rocks and minerals in Jordan. University of Jordan, Amman.

[37] Jarar, G., Baumann, A. and Wachendorf, H. (1983) Age determination in the Precambrian basement of the Wadi Araba Area, Southwest Jordan. Earth and Planetary Science Letters, 63, 292-304. doi:10.1016/0012-821X(83)90043-2

[38] Natural Resources Authority (2010) Mining sector performance during 2010. Annual Report, Investment and International Cooperation Division, Amman.

[39] Jordan Phosphate Mining Company (2011) Annual Report of Jordan Phosphate Mines Company, Amman.

[40] Haddadin, M. and Teimeh, M. (1982) Report on the limestone of Lubban. Unpublished Report, The NRA, Amman.
[41] Technostone, S.P.A. (1984) On feldspars, El Quweira area. Study for the exploitation of deposits of lithic materials in Jordan. Final Report, Public Mining Co., Amman.

[42] El-Hiyari, M. and Abed, A.M. (1985) Distribution and geology of the gypsum horizon in West Central Jordan. Proceeding to the Second Jordanian Geologic Conference, Amman, 21-24 October 1985, 396-419.

[43] Tarawneh, B. (1985) The geology of A-Hisa (Ali'na) Map Sheet No. 3151-I. The NRA, Amman.

[44] Barjous, M. (1986) The geology of Siwaqa Map Sheet No. 3252-IV. The NRA, Amman.

[45] Basem, K.M. (1996) Evaluation of some Jordanian limestone as building stone. Unpublished Ph.D. Thesis, University of London, London.

[46] Tarawneh, K. and Abu Qubu, J. (1998) Evaluation of the geological and engineering properties of some selected nummulitic limestone rocks of Ma'an area, South Jordan. 3rd Jordanian Mining Conference, Amman, 20-23 September 1998, 501-520.

[47] Abu Salah, A., Mneizel, S. and Aref, E. (1999) Pure limestone deposits in Al Hassa area. Unpublished Report, the NRA, Amman.

[48] Mdanat, M. and Ghannam, A. (2003) Occurrences of pure limestone deposits in Al Abiad, Jurf Edrawesh, Swaqa and Damekhi. Unpublished Report, The NRA, Amman.

[49] Kailani, G. (1989) Dolomite occurrences in the area between Wadi Isal and Wadi Aheimer Isal. Unpublished Report, The NRA, Amman.

[50] Nassir, S. and Khouri, H. (1982) Geology, mineralogy and petrology of Daba marble. Dirasat, 4, 107-130.

[51] Al Kailani, G. (1988) Calcium carbonate project, Wadi Isal. The NRA, Amman.

[52] Fadda, E. (1996) The geology of Wadi El Ghadaf area: Map sheet 3353-II. The NRA, Amman.

[53] Fadda, E. (1998) The geology of Wadi Ed-Dabi area: Map sheet 3353-III. The NRA, Amman.

[54] Hunjul, N. (2001) The geology of Qaser Al-Harana: Map sheet No. 3253-II. The NRA, Amman.

[55] Abu Gudiereh, M, (1998) Integrated studies on Azraq Basin. Unpublished report on minerals sector, The NRA, Amman.

[56] Mdanat, M. and Ghannam, A. (2002) Chalk occurrences in Azraq Basin. Unpublished report, the NRA, Amman.

[57] Ala'li, J. (2001) Evaluation and beneficiation of silica sand and kaolinitic sandstone in South of Jordan. Unpublished Ph.D. Thesis, Nottingham University, Nottingham.

[58] Alali, J. (1991) Assessment of Azraq diatomaceous clay, Jordan. Unpublished Master of Science Thesis, Leicester University, Leicester.

[59] Alali, J. (1994) Preliminary assessment of diatomaceous clay in Azraq depression, Jordan. Proceeding of the 5th Jordanian Geological Conference, Amman, 21-23 October 1994, 65-75.

[60] Khoury, H. and El Sakka, W. (1986) Mineralogical and industrial characteristics of Batun El Goul clay deposit 
Southern Jordan. Applied Science, 1, 321-351.

[61] Haddadin, M. (1974) Possibilities of bentonite in Jordan. Internal report, The NRA, Amman.

[62] Jasser, D. (1978) Investigation of Azraq clays. Internal report, the NRA, Amman.

[63] Khoury, H. (1980) Mineralogy and origin of Azraq clay deposits. Dirassat, 7, 21-31.

[64] Ibrahim, K. (1992) The geology of Al-Azraq map sheet No. 5355-I, scale 1:50,000. The NRA Bulletin, 36, 67.

[65] Ala'li, J. and Abu-Salah, A. (1993) Exploration for bentonite and other minerals in Azraq depression. Internal Report, The NRA, Amman.

[66] Dwairi, I. and Salam, M. (1994) Evaluation of bentonitic clays of Azraq for foundry sand uses. First Jordanian Mining Conference, Amman, 15-17 November 1994, 2537.

[67] Nawasreh, M. (2001) Azraq clay minerals. Ph.D. Thesis, Cardiff University, Cardiff.

[68] Teimeh, M. (1984) Gypsum occurrences of Jable Mulayh area, Tafila. The NRA, Amman.

[69] Teimeh, M. and Hiyari, M. (1978) Report on the gypsum occurrences in Southern Jordan. The NRA, Amman.

[70] El-Hiyari, M. and Abed, A. (1987) Distribution and geology of gypsum horizon in West-Central Jordan, In: El Isa, Z., et al. Eds., Geology of Jordan and Adjacent Areas, Jordanian Geologists Association, Amman, 55-67.

[71] Haddadin, M. (1976) Beneficiation studies of the medium grained alkali granites of the Aqaba-Quweira area. The NRA, Amman.

[72] Pical, Z. and Gharaibeh, R. (1969) Leucogranites in Southern Jordan, a potential source of feldspar raw material. The NRA, Amman.

[73] Hakki, W. (1976) Medium grained alkali granites of the Aqaba-Quweira area for use as a source of feldspar for ceramics. The NRA, Amman.

[74] Haddadin, M. and Barakat, H. (1988) Field study of medium to coarse granite crushed alkali granite deposit of East Aqaba area. The NRA, Amman.

[75] Barjous, M. (1997) An outline examination of a processing plant design for feldspar recovery from Jordanian granite sample. The Second Jordanian Mining Conference, Amman, 20-23 October 1997, pp. 30-39.

[76] Barjous, M. (2000) Beneficiation of Jordanian feldspar from unique tectonically crushed granite. The 3rd Jordanian International Mining Conference, Amman, 17-20 November 2000, 15-23.

[77] Ibrahim, K. (1993) The geology of Al-Azraq: Map sheet No. 3353. The NRA, Amman.

[78] Tarawneh, K., El Hamed, S., Abdelhadi, N. and Rabba, I. (2001) Evaluation of the geological and engineering properties of the basalt of Northeast Jordan for construction uses (case study). Engineering Association, Amman.

[79] Ibrahim, K., Rabba, I. and Tarawneh, K. (2001) Mineral resources map of the Northern Badia region Scale 1:250,000 using integrated landsat data and geological mapping. The 7th Jordanian Geological Conference, Amman, 13-15 October 2001, Book of Abstracts, 33.
[80] Tarawneh, K. (2003) Mineral occurrences in the Badia region/NE Jordan. Geology and Geophysics, 46 167-170.

[81] Dwairi, M. (1987) A chemical study of the palogonite tuffs of the Aritain area of Jordan: With special reference to the nature, origin and industrial potential of the associated zeolite deposits. Unpublished Ph.D. Thesis, Hull University, Hull.

[82] Ibrahim, K. (1996) Geology, mineralogy, chemistry, origin and uses of the zeolite. Unpublished Ph.D. Thesis, University of London, London.

[83] Dwairi, M. (1998) Evaluation of Jordanian zeolite tuff as a controlled slow-release fertilizer for $\mathrm{NH}_{4}^{+}$. Environmental Geology, 34, 1-4. doi:10.1007/s002540050251

[84] Dwairi, M. (1992) Jordanian zeolites evaluation for possible industrial application for natural aritain phillipsite tuffs. Dirasat, 19B, 23-43.

[85] Dwairi, M. (1993) Evaluation of the phillipsite tuff from NE Jordan as a drying agent. Abhath Al-Yarmouk, Pure Science and Engineering, 2, 75-85.

[86] Gharir, A.M. (1998) The distribution, nature, origin and economic potential of zeolite deposits in Uneiza, Mukawer and Tell Hassan of Jordan. Unpublished Master of Science Thesis, University of Jordan, Amman.

[87] Madanat, M. and Mehyar, N. (1999) Occurrences of zircon in Wadi Al-Mezrab area. The NRA, Amman.

[88] Masri, A. (1988) The geology of Wadi El Mezrab area at scale 1:10.000. The NRA, Amman.

[89] Nawasreh, M. (2001) Zircon sand: Investigation of Jordanian industrial minerals. Cardiff University, Cardiff.

[90] Sunna, B. (1970) Geological and petrological studies on some copper and manganese occurrences at Finan District-Wdi Araba, Jordan. The NRA, Amman.

[91] Nimry, F. (1973) The copper and manganese prospects of Wadi Araba. Report on phase one, The NRA, Amman.

[92] Hagen, D. (1980) Follow-up investigations on copper anomalies in Wadi Abu Khusheiba/Wadi Araba, Jordan. Unpublished Report, The NRA, Amman.

[93] Rabba, I. (1993) Investigation and processing of copper in Wadi Araba, Jordan. Unpublished Master Science Thesis, Wales University, London.

[94] BRGM, (1993) Wadi Araba copper target study: EEC project, No. Sem/30/628/013. The NRA, Amman.

[95] BRGM, (1994) Geochemical and mineral exploration of Aqaba-Araba complex. Final report: Economic geology project (EEC Project No. Sem/03/628/013). The NRA, Amman.

[96] Khoury, H.N. (1986) On the origin of copper-manganese deposits, Wadi Araba, Jordan. Dirasat, 13, 227-247.

[97] Nimry, F. (1967) The manganese occurrences at Wadi Dana, Jordan. Unpublished Master of Science Thesis, University of Leicester, Leicester.

[98] Tarawneh, K., Al Nawafleh, H., Moumani, K., Harahsheh, M., Tarawneh, B. and Abdelghafour, M. (2010) Mineralogy, geochemistry and genesis of the ferruginous sandstone in Batn Al Ghul Area/Southern Jordan. 7th International Symposium on Eastern Mediterranean Geology, 
Adana, 20-23 June 2010, Book of Abstracts, 45.

[99] Rabba, I. and Qararra, M. (2002) Mineralogical studies of gold occurrences in Wadi Abu Khushayaba area. Unpublished report, The NRA, Amman.

[100] Alnawafleh, H. (2007) Geological factors controlling the variability of maastrichtian bituminous rocks in Jordan. Ph.D. Thesis, Nottingham University, Nottingham.
[101] Alnawafleh, H., Al-Tarawneh, K., Ghannam, A. and AbuSa'ad, L. (2012) Preliminary study of a newly discovered subsurface oil shale deposit in southern Jordan. 32nd Oil Shale Symposium, Colorado, 12-17 October 2012, 66.

[102] Hamarneh, Y. (1998) Oil shale resources development in Jordan. Unpublished report, The NRA, Amman. 